\title{
Analysis of Strength of Concrete with Partial Replacement of Cement with Fly Ash and Fine Aggregate with Blast Furnance Slag Sand
}

\author{
${ }^{1}$ Nishant Meshram, ${ }^{2}$ Dr. Basavaraj S Balapgol \\ ${ }^{1}$ PG Student, ${ }^{2}$ Professor, Civil Department(C\&M), DYPCOE, Akurdi, Pune, Maharashtra, India. \\ 1'nishant.meshram1995@gmail.com, ${ }^{2}$ balapgolb@gmail.com
}

Abstract The utilization of waste materials from the industries has been continuously gaining emphasis in the construction work recently. The present work is to use Processed Granulated Blast Furnace Slag Sand and Fly ash as combined replacement for river sand and ordinary Portland cement respectively. M35 grade of concrete with W/C 0.4 will be adopted with two percentages of cement replacement by Fly Ash i.e, 30\% and 40\%, along with this the slag sand is varied from $0 \%$ to $100 \%$ in step of $20 \%$. In first variation, $30 \%$ Fly Ash is replaced by cement and slag sand is varied as $0 \%, 20 \%, 40 \%, 60 \%, 80 \%$ and $100 \%$. In second variation, $40 \%$ GGBS is replaced with cement and slag sand is varied as $0 \%, 20 \%, 40 \%, 60 \%, 80 \%$, and $100 \%$. For all mixes compressive strength, split tensile and flexural strength will be determined at different days of curing. The strength of cube specimens, cylinders and beams will be determined and compared with conventional concrete specimens. The beams are tested for flexure, under two point loading condition. Different parameters will be investigated in detail. In this paper literature is reviewed in detail to understand the experimental analysis.

Keywords - GGBS, Slag Sand, Fly ash, Compressive Strength, Split Tensile strength, Flexural Strength of Beams.

\section{INTRODUCTION}

Concrete is the largest man made material on earth. It contains cement, fine aggregate, coarse aggregate \& water. Among these $70 \%$ to $75 \%$ volume of concrete is occupied by coarse and fine aggregate, rest of about $25 \%$ to $30 \%$ is cement and water in form of cement paste. Beside these elements, chemical and mineral admixtures are added to enhance the properties of concrete. The large production of cement causes destruction of environment (Global Warming) and the continues use of Natural Sand leads to the depletion of river beds results into the ecological imbalance. Therefore the replacement of cement and natural sand by the industrial waste by-products (Mineral admixtures) has been continuously emphasized during recent years. In this study, the cement is partially replaced by Fly ash and natural sand is partially replaced by slag sand in various percentages. Fly ash and blast furnance slag sand are waste product obtained from Iron and steel manufacturing industry. Therefore the disposal problem of waste material is solved side by side the saving of cement and natural sand can be done.

\section{Problem Statement}

Worldwide, the cement industry is facing growing challenges in conserving material and energy resources, as well as reducing $\mathrm{CO} 2$ emissions.At the same time, the cement industry is facing challenges such as cost increases in energy supply, requirements to reduce CO 2 emissions, and the supply of raw materials in sufficient qualities and amounts so the partial replacement of materials like mineral admixture are used. M Sand is manufactured by crushing hard rocks and quarry stones into pieces. Special Knowledge and Technology is required for production of $\mathrm{M}$ - Sand and it is non - renewable resources.

\section{Aim And ObJECTIVES}

The main aim of this project is to highlight the performance of concrete with the use of ground granular blast furnace slag sand and fly ash as Supplementary cementitious material in construction industries and to increase its application in concrete.

- To study the effect on physical properties concrete combined with fly ash and slag sand by conducting workability tests

- To compare the mechanical properties of fly ash and slag sand concrete, with conventional concrete.

- To check durability Parameters of Concrete with partial replacement of Cement with fly ash and aggregates with slag sand. 
- To carry out Economic Feasibility comparing flyash,slag sand concrete.

conventional concrete and and partial replacement of

IV. LITERATURE REVIEW

\begin{tabular}{|c|c|c|}
\hline Sr.No. & Author Name/Research Paper & Finding/Outcomes \\
\hline 1 & $\begin{array}{l}\text { V.R. Prasath Kumar et.al - Characterization } \\
\text { study on coconut shell concrete with partial } \\
\text { replacement of cement by GGBS }\end{array}$ & $\begin{array}{l}\text { - The coarse aggregate is completely replaced with coconut shell. } \\
\text { - To enhance the coconut shell concrete property, cement is partially replaced with } \\
\text { GGBS. } \\
\text { - The micro-structural characterization has proved that incorporating GGBS has } \\
\text { improved the hydration process. } \\
\text { - The IMM study has clearly shown improvisation in the interfacial transition zone (ITZ) } \\
\text { of coconut shell concrete. }\end{array}$ \\
\hline 2 & $\begin{array}{l}\text { Meriem Senani et.al - Substitution of the } \\
\text { natural sand by crystallized slag of blast } \\
\text { furnace in the composition of concrete - } \\
\text { Alexandria Engineering Journal (2016) }\end{array}$ & $\begin{array}{l}\text { - The author investigates on the Substitution of the natural sand by crystallized slag of } \\
\text { blast furnace in the totally or partially composition of concrete. } \\
\text { - On adding Crystallized sand slag in proportions improves the compressive and tensile } \\
\text { strength. } \\
\text { - Interest in reducing the cost of Concrete. }\end{array}$ \\
\hline 3 & $\begin{array}{l}\text { Gaurav Singha et.al - Study of Granulated } \\
\text { Blast Furnace Slag as Fine Aggregates in } \\
\text { Concrete for Sustainable Infrastructure - } \\
\text { Procedia - Social and Behavioral Sciences } 195 \\
\text { ( } 2015 \text { ) } 2272-2279\end{array}$ & $\begin{array}{l}\text { - The compressive strength of concrete increases with increase in GBFS percentage up to } \\
\text { a certain percentage and after that it decrease following a Gaussian Model. } \\
\text { - The most optimum percentage of GBFS to be used in normal conditions considering } \\
\text { both strength and economy factor is from } 40 \% \text { to } 50 \% \text { and for marine conditions its } \\
\text { from } 50 \% \text { to } 60 \% \text {. } \\
\text { - The long term strength development of GBFS concrete is almost double of normal } \\
\text { concrete in both normal and marine conditions. }\end{array}$ \\
\hline 4 & $\begin{array}{l}\text { ZemeiWu, et.al - Comparative study on } \\
\text { flexural properties of ultra-high performance } \\
\text { concrete with supplementary cementitious } \\
\text { materials under different curing regimes - } \\
\text { Construction and Building Materials } 136 \\
\text { (2017) } 307-313\end{array}$ & $\begin{array}{l}\text { - The compressive and flexural properties of UHPC with different GGBS or fly ash } \\
\text { contents } \\
\text { - The optimal GGBS and fly ash contents for flexural behavior of UHPC were } 40 \% \text { and } \\
20 \% \text {, respectively } \\
\text { - Standard curing under standard, hot water, and steam curing were systematically } \\
\text { studied. }\end{array}$ \\
\hline 5 & $\begin{array}{l}\text { Aliakbar Gholampour, et.al - Performance of } \\
\text { sustainable concretes containing very high } \\
\text { volume Class-F fly ash and ground granulated } \\
\text { blast furnace slag - Journal of Cleaner } \\
\text { Production } 162 \text { (2017) } 1407 \mathrm{e} 1417\end{array}$ & $\begin{array}{l}\text { - The Fly Ash and GGBS is partially replaced by weight of high volume of cement by } \\
\text { different percentages. } \\
\text { - High volume use of FA and GGBS in concrete with the possibility of significantly } \\
\text { reducing its environmental impact. }\end{array}$ \\
\hline
\end{tabular}

\section{MeThodology}

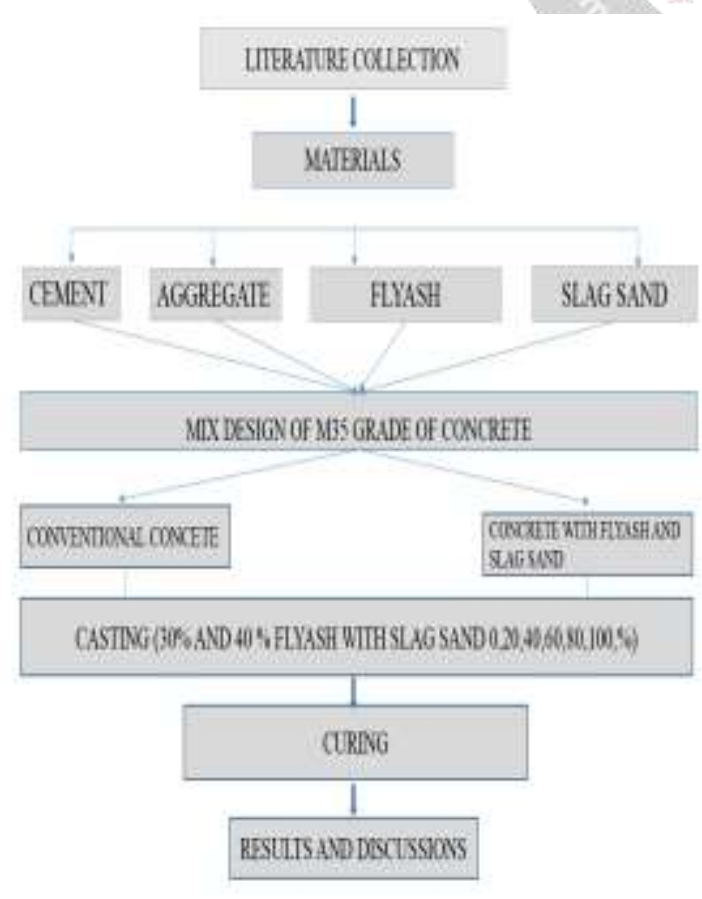

\section{EXPERIMENTAL INVESTIGATION}

\section{A. Cement}

OPC 53 Grade cement is required to conform to BIS specification IS:12269-1987 with a designed strength for 28 days being a minimum of $53 \mathrm{MPa}$ or $530 \mathrm{~kg} / \mathrm{cm}^{2} .53$ Grade OPC provides high strength and durability to structures because of its optimum particle size distribution and superior crystallized structure.

Table No. 1 - Physical Properties of Cement

\begin{tabular}{|c|c|c|c|c|}
\hline \multirow[t]{2}{*}{$\begin{array}{l}\text { Sr. } \\
\text { No. }\end{array}$} & \multirow[t]{2}{*}{ Name of Test } & \multirow[t]{2}{*}{ Units } & \multirow[t]{2}{*}{$\begin{array}{c}\text { Test } \\
\text { Results }\end{array}$} & $\begin{array}{c}\text { Specified } \\
\text { Limit (IS } \\
12269- \\
2013 \text { ) }\end{array}$ \\
\hline & & & & 53 Grade \\
\hline \multirow[t]{2}{*}{1} & \multirow{2}{*}{$\begin{array}{c}\text { Standard } \\
\text { Consistency }\end{array}$} & $(\%)$ & 42 & \multirow[t]{2}{*}{---} \\
\hline & & Temperature & $27+/-2$ & \\
\hline 2 & Density of cement & $(\mathrm{g} / \mathrm{cc})$ & 3.2 & --- \\
\hline 3 & $\begin{array}{c}\text { Initial Setting } \\
\text { Time }\end{array}$ & $(\min )$ & 195 & 30 Min \\
\hline 4 & Final Setting Time & $(\min )$ & 280 & $600 \mathrm{Max}$ \\
\hline 5 & $\begin{array}{l}\text { Soundness by Le- } \\
\text { Chateliers Method }\end{array}$ & $(\mathrm{mm})$ & 1 & $10 \mathrm{~mm}$ Max \\
\hline 6 & Fineness by Dry & $(\%)$ & 3.4 & $10 \% \operatorname{Max}$ \\
\hline
\end{tabular}




\begin{tabular}{|c|c|c|c|c|}
\hline & Sieving & & & \\
\hline \multirow[t]{3}{*}{7} & $\begin{array}{c}3 \text { Days } \\
\text { Compressive } \\
\text { Strength }\end{array}$ & \multirow[t]{3}{*}{$\left(\mathrm{N} / \mathrm{mm}^{2}\right)$} & 42 & 27 Min \\
\hline & $\begin{array}{c}7 \text { Days } \\
\text { Compressive } \\
\text { Strength }\end{array}$ & & 52 & 37 Min \\
\hline & $\begin{array}{c}28 \text { Days } \\
\text { Compressive } \\
\text { Strength } \\
\end{array}$ & & 65 & $53 \mathrm{Min}$ \\
\hline
\end{tabular}

\section{B. Fly Ash}

Fly ash from pulverized coal combustion is categorized as such a pozzolan. Fly ash or flue ash, also known as pulverised fuel ash is a coal combustion product that is composed of the particulates that are driven out of coalfired boilers together with the flue gases.

Table No. 2 - Physical Properties of Fly Ash

\begin{tabular}{|c|c|c|c|c|}
\hline $\begin{array}{c}\text { Sr. } \\
\text { No. }\end{array}$ & Name of Test & Units & $\begin{array}{c}\text { Test } \\
\text { Results }\end{array}$ & $\begin{array}{c}\text { Specified } \\
\text { Limits }\end{array}$ \\
\hline 1 & $\begin{array}{c}\text { Standard } \\
\text { Consistency }\end{array}$ & $\%$ & 25 & - \\
\hline 2 & $\begin{array}{c}\text { Fineness ( Reside } \\
\text { on 45 micron } \\
\text { sieve ) }\end{array}$ & $\%$ & 30 & $50 \mathrm{Max}$ \\
\hline 3 & $\begin{array}{c}\text { Initial Setting } \\
\text { Time }\end{array}$ & Minutes & 160 & - \\
\hline 4 & $\begin{array}{c}\text { Final Setting } \\
\text { Time }\end{array}$ & Minutes & 280 & - \\
\hline 5 & 7 Days CS & $\mathrm{N} / \mathrm{mm}^{2}$ & 30 & - \\
\hline 6 & 28 Days CS & $\mathrm{N} / \mathrm{mm}^{2}$ & 47 & - \\
\hline \multicolumn{4}{|c|}{} \\
\hline
\end{tabular}

\section{Coarse Aggregate}

Coarse-grained aggregates will not pass through a sieve with $4.75 \mathrm{~mm}$ openings (No. 4). Those particles that are predominantly retained on the $4.75 \mathrm{~mm}$ (No. 4) sieve and will pass through 3 -inch screen, are called coarse aggregate. The coarser the aggregate, the more economical the mix. Larger pieces offer less surface area of the particles than an equivalent volume of small pieces. Use of the largest permissible maximum size of coarse aggregate permits a reduction in cement and water requirements. Using aggregates larger than the maximum size of coarse aggregates permitted can result in interlock and form arches or obstructions within a concrete form. That allows the area below to become a void, or at best, to become filled with finer particles of sand and cement only and results in a weakened area.

Table No.3 - Sieve analysis for Coarse Aggregate

Fineness Modulus

\begin{tabular}{|c|c|}
\hline Details & Result $(20 \mathrm{~mm})$ \\
\hline Fineness Modulus & 8 \\
\hline
\end{tabular}

Table No.4 - Specific Gravity \& Water Absorption of $20 \mathrm{~mm}$ Coarse Aggregate IS: 2386 (Part 3)

\begin{tabular}{|c|c|c|}
\hline $\begin{array}{r}\text { Sr. } \\
\text { No. }\end{array}$ & Details & CA $(20 \mathrm{~mm})$ \\
\hline 1 & Specific Gravity & 2.64 \\
\hline 2 & Apparent Specific Gravity & 2.76 \\
\hline 3 & Water Absorption & 1.765 \\
\hline
\end{tabular}

Table No.5 - Aggregate Impact Value IS: 2386 (Part-4)

\begin{tabular}{|c|c|c|}
\hline $\begin{array}{c}\text { Sr. } \\
\text { No. }\end{array}$ & Details & CA $(20 \mathrm{~mm})$ \\
\hline 1 & Aggregate Impact Value & $18.6 \%$ \\
\hline
\end{tabular}

Table No.6 - Flakiness and Elongation Test (IS) 2386 Part 1 (For 20mm Aggregate)

\begin{tabular}{|c|c|c|}
\hline $\begin{array}{r}\text { Sr. } \\
\text { No. }\end{array}$ & Details & CA $(20 \mathrm{~mm})$ \\
\hline 1 & Flakiness Index\% & 35.17 \\
\hline 2 & Elongation\% Index & 45.2 \\
\hline 3 & Combined (EI+FI) $\%$ & 80.37 \\
\hline
\end{tabular}

\section{Fine Aggregate}

Quality of sand is as much of importance as other materials for concrete. Aggregate most of which pass through 4.75 $\mathrm{mm}$ IS sieve is known as fine aggregate. Fine aggregate shall consists of natural sand, crushed stone sand, crushed gravel sand stone dust or arable dust, fly ash and broken brick (burnt clay). Fine aggregate is the essential ingredient in concrete that consists of natural sand or crushed stone. The quality and fine aggregate density strongly influence the hardened properties of the concrete.

Table No.7- Sieve Analysis for Fine Aggregate

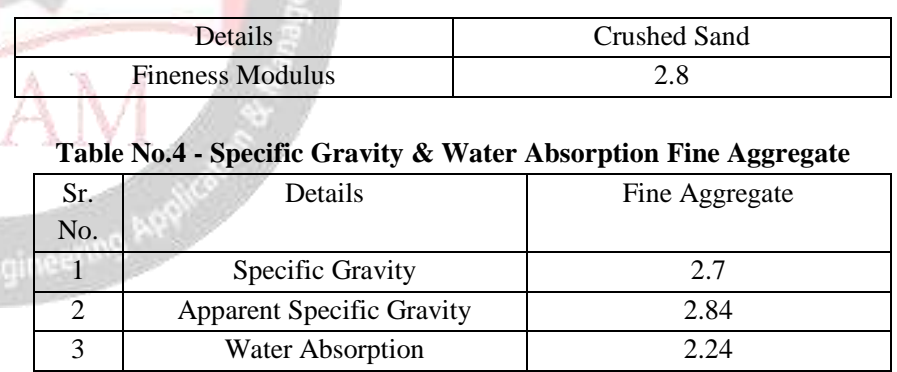

\section{E. Slag Sand}

Slag sand obtained from JSW, Bellary District is used. Locally available natural sand is also used in the work. Slag sand and natural sand confirming to Zone II asper (IS 3831970) are used The use of granulated slag as sand in the composition of concrete can meet two objectives that have a direct relationship with the cost of concrete: minimizing the amount of cement in the concrete composition and increasing the mechanical characteristic of concrete.

Table No.7- Sieve Analysis for Slag Sand

\begin{tabular}{|c|c|}
\hline Details & Slag Sand \\
\hline Fineness Modulus & 3.357 \\
\hline
\end{tabular}


Table No.4 - Specific Gravity \& Water Absorption Slag Sand

\begin{tabular}{|c|c|c|}
\hline $\begin{array}{c}\text { Sr. } \\
\text { No. }\end{array}$ & Details & Slag Sand \\
\hline 1 & Specific Gravity & 2.65 \\
\hline 2 & Apparent Specific Gravity & 2.85 \\
\hline 3 & Water Absorption & 2.86 \\
\hline
\end{tabular}

\section{REFERENCES}

[1] V.R. Prasath Kumar, K. Gunasekaran, T. Shyamala Characterization study on coconut shell concrete with partial replacement of cement by GGBS - Journal of Building Engineering 26 (2019) 100830

[2] Rami A. Hawileh, Jamal A. Abdalla, Fakherdine Fardmanesh, Poya Shahsana, Abdolreza Khalili Performance of reinforced concrete beams cast with different percentages of GGBS replacement to cement Archives of Civil and Mechanical Engineering 17 (2017) $511-519$

[3] Sorabh Saluja , Kulwinder Kaur , Shweta Goyal , Bishwajit Bhattacharjee - Assessing the effect of GGBS content and aggregate characteristics on drying shrinkage of roller compacted concrete - Construction and Building Materials 201 (2019) 72-80

[4] Gaurav Singh, Souvik Das, Abdulaziz Abdullahi Ahmed, Showmen Saha ,Somnath Karmakar - Study of Granulated Blast Furnace Slag as FinemAggregates in Concrete for Sustainable Infrastructure - Procedia Social and Behavioral Sciences 195 (2015) 2272 2279

[5] Meriem Senani, Noureddine Ferhoune , Abdelhamid Guettal - Substitution of the natural sand by crystallized slag of blast furnace in the composition of concrete Alexandria Engineering Journal (2016)

[6] Aissa Bouaissi, Long-yuan Li, Mohd Mustafa Al Bakri Abdullah , Quoc-Bao Bui - Mechanical properties and microstructure analysis of FA-GGBS-HMNS based geopolymer concrete - Construction and Building Materials 210 (2019) 198-209

[7] K. Ramakrishnan , G. Pugazhmani , R. Sripragadeesh , D. Muthu , C. Venkatasubramanian - Experimental study on the mechanical and durability properties of concrete with waste glass powder and ground granulated blast furnace slag as supplementary cementitious materials - Construction and Building Materials 156 (2017) 739-749

[8] An Cheng, Ran Huang, Jiann-Kuo Wu, Cheng-Hsin Chen - Influence of GGBS on durability and corrosion behavior of reinforced concrete - Materials Chemistry and Physics 93 (2005) 404-411

[9] A. Oner , S. Akyuz - An experimental study on optimum usage of GGBS for the compressive strength of concrete - Cement \&amp; Concrete Composites 29 (2007) 505-514

[10]Aliakbar Gholampour, Togay Ozbakkaloglu Performance of sustainable concretes containing very high volume Class-F fly ash and ground granulated blast furnace slag - Journal of Cleaner Production 162 (2017) $1407 \mathrm{e} 1417$

[11]Sina Dads tan, Jiping Bai - Mechanical and microstructural properties of self-compacting concrete blended with metakaolin, ground granulated blastfurnace slag and fly ash - Construction and Building Materials 146 (2017) 658-667

[12]P.J. Wainwright, N. Rey - The influence of ground granulated blastfurnace slag (GGBS) additions and time delay on the bleeding of concrete - Cement \&amp; Concrete Composites 22 (2000) 253-257

[13] Jianhe Xie , Junjie Wang, Bingxue Zhang, Chi Fang, Lijuan Li - Physicochemical properties of alkali activated GGBS and fly ash geopolymeric recycled concrete - Construction and Building Materials 204 (2019) 384-398

[14] Syamak Tavasoli, Mahmoud Nili, Behrad Serpoosh Effect of GGBS on the frost resistance of selfconsolidating concrete - Construction and Building Materials 165 (2018) 717-722

[15]P. Ganesh , A. Ramachandra Murthy - Tensile behaviour and durability aspects of sustainable ultrahigh performance concrete incorporated with GGBS as cementitious material. 